Scottish Geographical Magazine

\title{
A bibliography of Scottish Topography
}

the Hon. Lord Guthrie LL.D.

To cite this article: the Hon. Lord Guthrie LL.D. (1917) A bibliography of Scottish Topography, Scottish Geographical Magazine, 33:8, 363-365, DOI: 10.1080/14702541708555195

To link to this article: http://dx.doi.org/10.1080/14702541708555195

\section{册 Published online: 30 Jan 2008.}

Submit your article to this journal ¿

Џ Article views: 3

Q View related articles ๘ 
admits that this treatment will be unpleasant in families where French and German have intermarried; but he trusts that those who are thus severed from their exiled kin will find recompense for their sacrifice in the honour of being French.

But is competition in coal and iron the best way to secure the prosperity of France? Professor de Launay remarks that the natural conditions of France and Germany are so different that the two countries are complementary. Hence the two countries should develop on different lines. France has the advantage of an unrivalled position for general commerce, with great ports on both the Atlantic and the Mediterranean so that both east and west are open to her trade, and through Algiers she has an open gateway into Northern Africa. Her ports are connected by magnificent internal waterways; she has incomparably the finest climate in Europe; her rainfall is good, the soil rich, and it is tilled by a race of supremely skilful agriculturists. Her people, with their intellectual and artistic gifts, their courage and independence, are one of the most valuable assets in modern civilisation; but they are not at their best when working in the shackles of industrialism. Professor de Launay's hopes may not be fully realised. If so, his disappointment will be bitter, and our sympathy with him keen; but it will be brightened by the faith that his is not the only way, and perhaps not the best way, to the highest welfare of France.

\section{A BIBLIOGRAPHY OF SCOTTISH TOPOGRAPHY.1}

By the Hon. Lord GuTHRIE, LL.D., President of the Royal Scottish Geographical Society.

SoMe inventors of "labour-saving" appliances make money and fame: Singer with his sewing machine, Cormack with his reaper, for instance. Now, dictionaries, encyclopædias, library catalogues, and bibliographies serve the same purpose in the realm of books. But their authors or editors seldom make their names illustrious, or line their pockets with anything more than the copper needed for daily bread. A popular author may owe his success to books, which he would never have heard of but for the subject-index, the encyclopedia snippet, or the bibliography; but of these his preface contains no acknowledgment.

Mr. Cash, in his "Contribution to the Bibliography of Scottish Topography," has rendered permanent and important service to Scottish geography. His work will be supplemented. He modestly calls it a "Contribution," and says in his preface: "Obviously this list can make no pretensions to completeness or finality." But it can never be superseded. The book really breaks fresh ground, although many lists have appeared of hooks dealing with particular Scottish counties; and

I A Contribution to the Bibliography of Scottish Topography. By the late Sir Artbur Mitchell, K.C.B, and O. G. Cash, F.R.S.G.S. 2 vols. Edinburgh: printed for the Scottish History Society, 1917 . 
Sir Richard Hoare in 1815, and Mr. J. P. Anderson in 1881, published catalogues of books relating to the topography of Great Britain and Ireland. The idea was the late Sir Arthur Mitchell's, and began with the modest intention to publish a topographical bibliography of his native province of Moray. Sir Arthur thereafter enlarged his plan so as to include all Scotland, with its islands; and, before Mr. Cash became his coadjutor, he had collected a mass of unarranged material, what Mr. Cash calls "a chaotio multitude of slips, thousands in number." About 1901, Sir Arthur asked Mr. Cash's help, which, fortunately for literary men, he was able to give. He devoted to the task much of his scanty leisure, not only in holiday time, but when burdened with other work, and conferred and corresponded with Sir Artbur Mitchell about muititudinous details, till Sir Arthur's death in 1909. Thereafter, Mr. Cash worked single-handed at an undertaking so immense that it might well have absorbed the labours of a large number of workers. In that case, however, while the number of entries might have been larger, the work, as a whole, would probably have lacked the uniformity of method which makes it so easy of reference.

A book of this nature might obviously be executed in many different ways. The two prime requisites are facility of reference and the minimum of repetition. In both these respects Mr. Cash's method is amply justified. The book is arranged in two main divisions, Topographical and Topical; the first volume deals with places and the second with subjects.

In the Topographical volume, the division is by counties, with the addition of three territories not limited by the boundaries of a single county, namely, the Borders, Galloway, and the Highlands and Islands. This county division is preceded by twelve pages of books containing general deseriptions of Scotland; anonymous volumes come first, followed by othors, arranged alphabetically, according to their author's names. Similarly, under counties, guides and general descriptions come before the enumeration of books relating to towns, villages, parishes, and districts. And, under the chief towns, the same method is pursued. For instance, take Aberdeenshire, which is alphabetically first in the list of counties. After books dealing with the whole county, we come, under "Aberdeen," to (1) Guides and General Description; (2) History; (3) Olden Aberdeen; (4) University; (5) Schools; (6) Churches-22 in number; (7) Societies, beginning with "Advocates, Anatomical, Boys" Brigade," and going on through "Freemasons," to "Shipmasters, Volunteers," etc. etc. ; (8) Views ; (9) Newspapers; and (10) Miscellaneous.

The second volume, dealing with subjects, is arranged under thirtyone heads, beginning with "Antiquitios, Architecture, and Art," and ending with "Theatre, Tours, Universities, and Views." The number of heads might have been indefinitely increased by sub-division. For example, the comprehensive heading "Folklore, Manners, Customs, Etc.." includes Satan's Invisible World discovered, with the marvellous History of Major Weir and his Sister, Dean Ramsay's Scotish Life and Character, and Allan Ramsay's Collection of Scots Proverbs, books which obviously admit of more minute classification. But Mr. Cash has done wisely in framing 
his work on broad and comprehensive lines, although perhaps the General Index at the end might have been more minute. It might, for example, have contained such titles as Witcheraft, which are included under more general heads.

Mr Cash's most useful book ought to be available to the general public, as well as to members of the Scottish History Society; and it ought to be in every public library. Like Mr. William Geddie's Bibliography of Middle Scots Poefs, issued in 1912 by the Scottish Text Society, such books could not be published by private enterprise. Yet it is unfortunate that they can only be procured by or through members of the Society issuing them. Mr. Cash has gone far afield, and has included works in Latin, French and German, as well as in English. Most of the entries are of published books, but he has ransacked as well the pages of magazines, and the Proceedings of learned Societies. The result, contained in 705 olearly but closely printed pageg, represents an amount of patient and highly skilled labour for which Mr. Cash will never get credit from the public, because it can only be appreciated by those with some experience in such work. Probably, had Mr. Cash anticipated the amount of drudgery involved, he never would have undertaken the task. The loss would have been great to many a litterateur and editor, who, thinking of the previously uncharted sea, will hold up his hands and bless, not General Wade, but Mr. Cash.

Erratum,-_"The Weddell Sta." On p. 251 of Dr. W. S. Bruce's article on this subject, the figures 1822 (line 12 from top) should read 1821 , making the date of Powell's discovery of the group bearing his name, 6th December 1821.

\section{PROCEEDINGS OF THE ROYAL SCOTTISH GEOGRAPHICAL SOCIETY.}

Meztring of Councid, July 19, 1917.

A Meming of Council was held on the 19th July, when the undermentioned ladies and gentlemen were elected Ordinary Members of the Society :-

Robert Findiay.

Alexander Lawson.

The following were elected Associate Members:-

Miss Kate Fraser.

Miss Jean S. White.

Charles O'Kane.

Miss Bella S. Littlejobn.

Robert H. Kinvig.

Miss Fletcher.

Miss N. C. Buckley. 